\title{
MATERIAEY
}

Lidia Pawelec

(Kielce)

\section{Reformy szkolne w pierwszej połowie XIX wieku}

Na początku XIX w., kiedy Polska przestała istnieć na mapie Europy, co światlejsi obywatele szukali nowych dróg zreformowania i unowocześnienia szkolnictwa, w tym również kształcenia nauczycieli, dostrzegając w takich działaniach szanse na ratowanie narodu. Nie ulega wątpliwości, że podobnie jak wszystkie ziemie polskie, również ziemia świętokrzyska potrzebowała szybkich zmian. Bo w spuściźnie pozaborczej Księstwo Warszawskie, utworzone w 1807 r. przez Napoleona, odziedziczyło szkolnictwo wyjątkowo zaniedbane: zrujnowane budynki, niski poziom nauczania i skąpe fundusze, a przede wszystkim brak wykwalifikowanych nauczycieli. Tymi ważnymi sprawami miała się zająć Izba Edukacyjna, powołana do życia przez Komisję Rządową 28 stycznia 1807 r. Skład osobowy tej tymczasowej władzy szkolnej tworzyli: Stanisław Kostka-Potocki (prezes), ks. Stanisław Staszic, Józef Lipieński, Józef Jeziorowski, ks. Adam Prażmowski, Walenty Sobolewski, ks. Onufry D. Kopczyński, Samuel B. Linde (rektor liceum warszawskiego, autor Stownika języka polskiego), Aleksander Potocki, ks. Karol B. Diehl (pastor Kościoła reformowanego) i ks. Schmidt (pastor Kościoła augsburskiego) ${ }^{1}$. Jednym z głównych dążeń Izby Edukacyjnej było nauczanie na poziomie elementarnym. Artykuł pierwszy ustawy szkolnej z 1808 r. stwierdzał, że: szkoły winny być w każdym mieście, miasteczku i wsi, a każde dziecko bez względu na wyznanie nie może być pozbawione szansy uczenia się w szkole. Paragraf 27 tejże ustawy głosił ponadto, że wszyscy rodzice obowiązani są posyłać swoje dzieci do szkoły. Niestety, najbliższe lata wykazały, że z powodu trudności, przede wszystkim finansowych, to postanowienie okazało się mało realne. Na ogół brakowało środków na utrzymanie szkół i nauczycieli. Dlatego też w 1811 r. prefekt departamentu radomskiego, obejmującego znaczny obszar obecnego województwa świętokrzyskiego, wydał odezwę zobowiązującą wszystkich mieszkańców miast i wsi do składania opłat lub gromadzenia zboża na rzecz nauczy-

1 S. Możdeń, Zarys historii wychowania (cz. II - Wiek XIX - do 1918 roku), Kielce 1993, s. 65; Także: Ł. Kurdybacha, Historia wychowania, t. 2, Warszawa 1996, s. 164. Źródła do dziejów wychowania i szkolnictwa $w$ Polsce z doby Izby Edukacji Publicznej 1807-1812, zebrał Z. Kukulski, Lublin 1932, s. 415-416. 
cieli $^{2}$. Porównując obszar Kielecczyzny z ziemią śląską, to tam, w zaborze pruskim, nowy etap polityki oświatowej zapoczątkował wydany w lipcu 1801 r., Regulamin szkolny dla niższych szkół katolickich w miastach i na wsi Ślaska oraz hrabstwa kłodzkiego ${ }^{3}$. W tymże regulaminie daje się zauważyć znaczne wyeksponowanie obowiązków nauczyciela w całokształcie pracy oświatowej w szkole, i nie tylko, bo również w lokalnym środowisku, a także źródeł jego opłacania, na które składało się też zboże, ziemniaki, drzewo opałowe itp.

W Księstwie Warszawskim szkoła miała być utrzymywana przez wszystkich mieszkańców, którzy tworzyć mieli tzw. towarzystwa szkolne albo parafię szkolną. By zabezpieczyć minimum funduszy na utrzymanie szkoły, ustalono, że towarzystwa szkolne liczyć będą około 200 gospodarzy. Stąd też niejednokrotnie tworzyło je kilka wsi o mniejszej liczbie mieszkańców. Z upływem czasu obszar ten nazywano obwodem szkolnym. Cytowana wcześniej ustawa określała też zakres ,wiadomości potrzebnych”, czyli program nauczania zatytułowany:,Urządzenie szkół miejskich i wiejskich elementarnych”. Stwierdzono w nim: „W szkole wiejskiej dzieci uczyć się mają: czytać druk i pismo, pisać, rachować na pamięć i cyframi do reguły trzech włącznie, nauki moralnej i religii. W klasie ostatniej, trzeciej, przydana będzie nauka zachowania zdrowia i wiadomości rolnicze: o zasiewie traw, pasiekach, chowie i leczeniu bydła itp., nauka prostego pomiaru gruntów, znajomości miar, wag i pieniędzy oraz znajomości praw wzajemnych między obywatelami. Na wiosnę i w jesieni będą się dzieci uczyły pielęgnować drzewa owocowe, warzywa i rośliny użyteczne. W szkołach miejskich doda się wiadomości przydatne dla handlu i przemysłu oraz rysunki rzemieślnicze, dla dziewcząt zaś naukę robót kobiecych i gospodarskich"4. W tak sformułowanym programie nauczania szczególnie pomocny okazał się elementarz Konstantego Wolskiego (1762-1810) pt. Nauka poczatkowego czytania, pisania i rachowania, oraz Przepisy dla nauczycielów dajacych nauke początkowego czytania $(1811)^{5}$. O szkołę i nauczyciela miały dbać dozory, na których jednocześnie spoczywała rola łączników między władzą administracyjną a społeczeństwem. Instrukcja Izby Edukacyjnej z 16 października 1808 r. ustanawiała trzystopniowy rodzaj dozorów: miejscowy, powiatowy i departamentowy ${ }^{6}$.

Ustanawiając tak sformułowane zasady zakładania i funkcjonowania szkół na wsiach i w miastach, Izba Edukacyjna pragnęła stworzyć podstawy do uniezależnienia się szkoły elementarnej od proboszcza i dziedzica. Oznacza to, że szkoła elementarna miała się stać instytucją społeczno-państwową i świecką.

W każdym razie na interesującym nas obszarze najlepsze rezultaty $\mathrm{w}$ rozbudowie sieci szkół elementarnych w okresie od połowy 1811 r. do jesieni 1812 r. osiągnięto w dwóch powiatach: olkuskim i miechowskim. W powiecie olkuskim dozory miejscowe

\footnotetext{
${ }^{2}$ A. Artymiak, Studia nad historia szkolnictwa elementarnego w obwodach kieleckim i olkuskim województwa krakowskiego (1816-1862), Wrocław - Warszawa - Kraków 1964, s. 21.

3 S. Gawlik, Dzieje kształcenia nauczycieli na Śląsku Opolskim (1765-1975), Opole 1979, s. 40.

${ }^{4}$ Cyt. za: S. Kot, Historia wychowania. Zarys podręcznikowy, wyd. drugie, t. 2, Lwów 1934, s. $242-243$.

${ }^{5}$ Cyt. za: S. Kot, Historia wychowania, t. 2, s. 242-243.

${ }^{6}$ W. Caban, Szkolnictwo elementarne na ziemi kielecko-radomskiej (1809-1862), Kielce 1983, s. 8; Także: S. Kot, Historia wychowania, t. 2, s. 242.
} 
zorganizowały 41 szkół, (zaś najwięcej szkół zorganizowano na obszarze dawnego powiatu lelowsko-siewierskiego).

Zakładanie szkół elementarnych na ziemi kielecko-radomskiej przebiegało nierównomiernie i zależało od aktywności lokalnych i powiatowych dozorów oraz sytuacji materialnej ludności. A ta ostatnia była szczególnie trudna, przede wszystkim w latach 1812-1814. Wtedy społeczeństwo żyło w powszechnej biedzie spowodowanej przemarszami wojsk i rekwizycjami oraz obowiązkiem dostarczania produktów żywnościowych na rzecz wkraczającej do Księstwa Warszawskiego armii carskiej ${ }^{7}$. I w takich warunkach odwoływanie się do społeczeństwa w sprawach oświatowych nie mogło przynieść pożądanych skutków.

Izba Edukacyjna, zmierzając do powszechności oświaty musiała zająć się również sprawami nauczycieli. W tym celu wydała 15 marca 1808 r. specjalną instrukcję ${ }^{8}$ Zgodnie z jej treścią nauczycielem w szkole elementarnej mogła zostać tylko ta osoba, która wcześniej udowodniła swe kwalifikacje przed rektorem szkoły średniej. Nie wiemy, czy taki rygor stosowano także wobec byłych wojskowych przyjmowanych na nauczycieli, choć nie mieli odpowiednich uprawnień. Prawdopodobnie główny argument stanowiła pełna poświęcenia się ojczyźnie służba wojskowa. Dodajmy, że wobec powszechnego braku nauczycieli z odpowiednimi kwalifikacjami egzaminatorzy nie stawiali wygórowanych wymagań osobom, które deklarowały się podjąć pracę w szkole elementarnej. Za jej wykonanie nauczyciel mógł otrzymać roczne wynagrodzenie w wysokości od 600 do 800 zł rocznie w mieście i od 500 do 600 zł rocznie na wsi. Ponadto nauczycielowi zapewniano jednomorgowy ogród ${ }^{9}$.

Kiedy w 1808 r. Izba Edukacyjna wprowadzała zasadę zatrudniania do szkół elementarnych osób, które udowodnią kwalifikacje poprzez egzamin, zdawała sobie sprawę, że ich przygotowanie będzie nieodpowiednie. Ważnym więc punktem wyjścia z kryzysowej sytuacji kadrowej w szkolnictwie, zwłaszcza w sferze poszerzania sieci szkolnej, było z jednej strony zatrudnianie kandydatów bez wymaganych kwalifikacji, z drugiej natomiast - kształcenie nauczycieli w seminariach nauczycielskich.

W czasach Księstwa Warszawskiego seminaria takie istniały w Łowiczu i Poznaniu. Dekret o utworzeniu seminarium w Łowiczu król pruski podpisał 30 czerwca $1804 \mathrm{r}$. Wtedy też rozpoczęło działalność seminarium poznańskie. Z chwilą ustanowienia Królestwa Kongresowego pozostało tylko seminarium w Łowiczu, ponieważ Poznań wszedł w skład zaboru pruskiego (Wielkie Księstwo Poznańskie). Instytut Łowicki, kształcąc ograniczoną liczbę uczniów nie był w stanie zapewnić potrzebnej liczby kwalifikowanych nauczycieli dla szkół elementarnych. W tej sytuacji władze zdecydowały się na otwarcie w 1819 r. drugiego seminarium. Był nim Instytut Nauczycieli Elementarnych i Organistów w Puławach, bo tak brzmiała oficjalna nazwa tego zakładu, działającego do 1855 r. $^{10}$

\footnotetext{
7 W. Caban, Szkolnictwo elementarne, s. 12 i 13.

8 Ibidem, s. 95.

9 Ibidem, s. 61.

${ }^{10}$ Ibidem, s. 96.
} 
Na wniosek S. Staszica z seminariów w Łowiczu i Poznaniu Izba Edukacyjna uczyniła nie tylko ośrodki kształcenia, ale także instytucje służące podnoszeniu kwalifikacji nauczycieli już pracujących w szkolnictwie. Trzyletni program nauczania opracował Burgund, rektor seminarium w Łowiczu. W pierwszych dwóch latach nauka obejmowała przedmioty ogólne, a w trzecim roku natomiast przygotowywanie pedagogiczne. Wydana w 1815 r. praca Wojciecha Izydora Chojnickiego, jednego z nauczycieli seminarium łowickiego pt. Zasady pierwiastkowe pedagogiki i dydaktyki [...] dla trudniacych sie edukacja publiczna i prywatna elementarna, przez wiele lat służyła za podręcznik pedagogiki ${ }^{11}$. Przy seminarium istniała także szkoła ćwiczeń, w której kandydaci pod okiem doświadczonego nauczyciela doskonalili umiejętności dydaktyczno-wychowawcze, oraz zdobywali wiadomości praktyczne i teoretyczne również w zakresie ogrodnictwa i pszczelarstwa. W 1814 r. do programów seminariów wprowadzono muzykę oraz śpiew kościelny, ułatwiając w ten sposób swoim absolwentom łączenie pracy nauczycielskiej z funkcją organisty. Oprócz obowiązków organisty nauczyciel szkoły elementarnej mógł uprawiać jakieś rzemiosło, np. tkactwo, ogrodnictwo, introligatorstwo, oraz dokonywać pomiarów gruntów chłopskich, sporządzać umowy między gospodarzami i prowadzić księgi rachunkowe. W trosce o pozycję społeczną nauczyciela nakazywano mu, ażeby unikał ,wszelkich wad obraźliwych i upadlających, toż nieprzyzwoitych zabaw i waśni z włościanami i domowników swoich od tego wstrzymywał, starając się, aby równie przykładem, jak i nauką był pożyteczny"12.

W czasach Księstwa Warszawskiego końcową decyzję o zatrudnieniu nauczyciela podejmowała Izba Edukacyjna. Kiedy więc kandydat złożył egzamin przed rektorem szkoły departamentowej lub wydziałowej, prefekt przesyłał Izbie Edukacyjnej dokumenty stwierdzające przygotowanie wraz z opinią o nienagannej postawie moralnej ubiegającego się o pracę w szkole. Na tej podstawie naczelne władze oświatowe kierowały patent na nauczyciela do dozoru powiatowego. Tenże patent wręczał pedagogowi w miejscu jego pracy i w obecności zebranych członków towarzystwa szkolnego przedstawiciel tegoż dozoru.

Obowiązki nauczycieli były ściśle określone przepisami centralnych władz oświatowych. Nauczyciel miał:

- przebywać w swojej szkole z wyjątkiem wakacji,

- czuwać nad frekwencją uczniów,

- składać miesięczne sprawozdania o postępach uczniów,

- zachęcać podopiecznych do nauki.

Zalecano również pedagogowi cierpliwość i łagodność ojcowską w pracy dydaktyczno-wychowawczej. Nauczyciel mógł podejmować dodatkowe prace, „które z pierwszymi powinnościami nauczycielskimi zgadzają się, to jest: być może pisarzem, tkaczem, introligatorem, ogrodnikiem itd.”. Zabraniano natomiast prowadzenia szynku i „bawienia się muzyką za pieniądze" "13. Jednym słowem nauczyciel miał postępować tak, by być

\footnotetext{
11 Ł. Kurdybacha, op.cit., s. 167-168.

12 Ibidem, s. 168.

13 Zbiór przypisów administracyjnych Królestwa Polskiego, Wydział Oświecenia, Warszawa 1866, t. 1, s. 87-91; Ł. Kurdybacha, op.cit., s. 168.
} 
wzorem dla wszystkich członków towarzystwa szkolnego. Burgund pisał w tej sprawie: „ten co ma przyszłych obywateli o obowiązkach nauczać, ich oświecać i moralnie dobrymi uczynić, powinien sam na sobie wprzód dać to poznać. Inaczej z młodzieży porobiłyby samych obłudników"14.

Ważnym więc punktem wyjścia w poglądach pedagogicznych Burgunda była edukacja moralna kandydatów. Wierzył przy tym, że najskuteczniejszą metodą wychowania moralnego jest postawa samych nauczycieli. Zalecał im również, by z treści podręczników ze szczególną pilnością wydobywali treści mające wysoką wartość moralną. Jako były zakonnik, ściśle łączył naukę o moralności z religią naturalną, którą uznawał za najbardziej uniwersalną. Był zdania, że przestrzeganie jej reguł ochroni seminarzystów przed nietolerancją, zabobonnością i niedowiarstwem ${ }^{15}$.

Główne kierunki kształcenia nauczycieli wypracowane przez pięcioletni okres istnienia Izby Edukacyjnej realizowała Dyrekcja Edukacyjna powstała w 1812 r. Ową ciągłość gwarantował Stanisław Potocki, kierujący jej pracami. Jemu też powierzono zwierzchnictwo nad Wydziałem Oświecenia powstałym w 1815 r. w miejsce Dyrekcji Edukacyjnej, a następnie został ministrem Komisji Rządowej Wyznań i Oświecenia Publicznego, utworzonej w $1817 \mathrm{r}^{16}$

Przy wielu różnych przeciwnościach, gdy w 1816 r. powstał Uniwersytet Warszawski, którego projekt przygotowała Komisja pod przewodnictwem Stanisława Staszica, przy Uniwersytecie utworzono Seminarium Nauczycielskie dla stypendystów. Oni to, oprócz zwyczajnych wykładów, korzystali z osobnej nauki literatury psychologii i pedagogiki ${ }^{17}$.

Kwalifikacje nauczycieli do zawodu regulowało zarządzenie Komisji Rządowej z dnia 11 marca 1817 r., ustalające: „Podług zwyczajów dotąd trwających wolno jest dozorom oddawać kandydatów na nauczycieli, że zaś takowymi muszą być osoby do tego kwalifikowane, przeto uznanie tej kwalifikacji należeć ma do rektorów szkół wyższych, to jest podwydziałowych, wydziałowych lub wojewódzkich najbliższych miejsca dozoru, a tymczasowe upoważnienie do dawania nauki od komisarza obwodu wychodzić będzie $^{18}$.

Nauczycieli kształconych w zakładach lub instytucjach przygotowujących do tego zawodu w 1817 r. było niewielu. Nawet 45 lat później, w 1862 r., najtrudniejszą do rozwiązania sprawę stanowił poważny niedobór sił nauczycielskich, a już pracujący często nie odpowiadali wymogom stawianym kandydatom do tego zawodu. Występujące braki niezbicie dowodzą, że czyniono niewiele, albo zbyt mało, by uruchamiać nowe seminaria kształcące nauczycieli na miarę występujących potrzeb społecznych.

\footnotetext{
14 Projekt tabelaryczny usposobienia seminarzystów według projektu Burgunda, początkiem: Źródła do dziejów wychowania, s. 298.

15 Ibidem, s. 231.

16 S. Kot, Historia wychowania, t. 2, s. 244.

17 Ibidem, s. 249.

18 A. Artymiak, op.cit., s. 54.
} 
W wymiarze Kielecczyzny nie było inaczej. Wiemy, że dnia 17 kwietnia 1829 r. rektor Szkoły Wojewódzkiej w Kielcach, ks. Andrzej Polejowski, wydał Janowi Fiszeyderowi świadectwo uprawniające do pracy nauczycielskiej w szkole wiejskiej. Głównym argumentem pozytywnej opinii, jaką otrzymał J. Fiszeyder, okazała się znajomość języka polskiego, niemieckiego i arytmetyki. Natomiast nic nie wiemy o kwalifikacjach Franciszka Backiewicza, przyjętego przez burmistrza na posadę nauczyciela do Małogoszcza, wcześniej pracującego w szkole elementarnej w Daleszycach ${ }^{19}$. Można więc zakładać, że nauczycielami stawały się osoby reprezentujące niski poziom wiedzy i umiejętności pedagogicznych. Niekiedy były to osoby przypadkowe, nawet bez jakichkolwiek kwalifikacji, a legitymujące się jedynie wtedy dosyć rzadką jeszcze umiejętnością pisania i czytania. Brak niezbędnego przygotowania fachowego nauczycieli powodował, że poziom nauczania w szkołach elementarnych był niski. Uczono w nich: czytania, pisania, poznawania zgłosek i zgłoskowania, redagowania pisma, katechizmu, i rachowania w sposób zupełnie dowolny, pozbawiony podstawowych reguł dydaktycznych.

Powyższe przykłady wskazują, że do 1860 r. stan szkolnictwa elementarnego był beznadziejny. Ale o wiele korzystniej przedstawiała się sytuacja szkolnictwa średniego, zwanego wówczas ,pierwszym”, a więc szkół wojewódzkich oraz zachowanych, zwłaszcza w pierwszym okresie, szkół wydziałowych i podwydziałowych. One to osiągnęły wysoki poziom nauczania, dzięki dobrym, często nawet wybitnym nauczycielom, którzy doszli później do stanowisk akademickich ${ }^{20}$.

Niechęć rządów carskich, czy wręcz wrogość wobec Polaków wywierała ujemny wpływ na wszystkie dziedziny życia społecznego, a zwłaszcza na szkolnictwo, oświatę i kulturę. Bo oczywiście chodziło o utrzymywanie społeczeństwa polskiego w ciemnocie i zacofaniu, co miało ułatwić realizację wzmożonej polityki rusyfikacyjnej, szczególnie po upadku powstania listopadowego, kiedy car Mikołaj I napisał do Iwana Paskiewicza, namiestnika Królestwa Polskiego „edukacja była zła i jej to przede wszystkim należy przypisać skłonność młodzieży do buntu" ${ }^{21}$. Nieustanne zmierzanie caratu do zastąpienia szkolnictwa polskiego rosyjskim łączyła się, zwłaszcza pod koniec XIX w. z hamowaniem jego rozwoju w sensie ilościowym i jakościowym, co ograniczało szanse na powszechność kształcenia ${ }^{22}$. Zresztą przestała ona istnieć znacznie wcześniej, bo po wprowadzeniu w 1851 r. ustawy szkolnej znoszącej obowiązek szkolny. Ta sama ustawa uwalniała mieszkańców miast i wsi od opłat na rzecz szkół, a kurator warszawski, Paweł Muchanow, nakazał nawet utrudnianie budowy nowych i remontu już istniejących obiektów szkolnych ${ }^{23}$.

W rezultacie tak zdefiniowanej polityki w latach 1851-1860 uległo likwidacji 239 szkół elementarnych, z czego 189 wiejskich. Niepokojąco szybko postępujący proces zmniejszania szkół elementarnych dowodzą następujące liczby: w roku 1850 było takich

\footnotetext{
19 Ibidem, s. 61.

20 Ibidem, s. 69.

${ }^{21}$ Cyt. Za: J. Draus, R. Terlecki, Historia wychowania, t. 2: Wiek XIX i XX, Kraków 2005, s. 83.

22 J. Grzywna, Związek Nauczycielstwa Polskiego na Kielecczyźnie 1905-1939, Kielce 1993, s. 13.

23 J. Draus, R. Terlecki, op.cit., s. 84. Także: S. Kot, Historia wychowania, t. 2, s. 264.
} 
szkół 751, pięć lat później (1855) istniało ich 655, czyli 11,4\% mniej. Następne lata przyniosły dalsze kurczenie się sieci szkół elementarnych. I tak: w 1860 r. działało 557 szkół, a w 1861 r. 554. Oznacza to, że w okresie od 1850 do 1861 r. liczba szkół zmniejszyła się o $197(13,5 \%)^{24}$. Tenże dramatycznie duży spadek liczby szkół elementarnych wynikał też z braku nauczycieli. Seminarium łowickie, przeniesione w 1845 r. do Radzyminia, kształciło skromną liczbę nauczycieli, bo władze zaborcze nie były tym zainteresowane, gdyż wychodziły z założenia, iż ,zbyt szerokie upowszechnienie oświaty wśród ludu polskiego może wywołać w przyszłości kłopoty dla rządu rosyjskiego”.

Znacznie lepiej od wiejskiego przedstawiał się stan szkolnictwa elementarnego w miastach, gdzie istniało wiele szkół prywatnych, na ogół zatrudniających nauczycieli o wyższym poziomie wykształcenia.

Kwalifikacje nauczycieli na Kielecczyźnie do 1851 r. określano przede wszystkim na podstawie egzaminu kwalifikacyjnego. Tacy właśnie nauczyciele stanowili trzon kadry pedagogicznej szkół elementarnych. Dla osób, które przerywając naukę w szkołach średnich zgłaszały się do pracy nauczycielskiej był to zawód pierwszy i często wiązali się z nim na długie lata. Ci nauczyciele najczęściej rekrutowali się z zubożałej szlachty i rodzin mieszczańskich. Drugą grupę nauczycieli, o wiele mniej liczną, stanowili absolwenci seminariów nauczycielskich. Pierwsze przypadki zatrudnienia wychowanków tych szkół zanotowano około 1820 i 1830 r. Władze wojewódzkie w Kielcach i Radomiu, pozostając w kontakcie z rektorami instytutów nauczycielskich, starały się zatrudniać w szkołach elementarnych ich wychowanków.

W okresie międzypowstaniowym liczba nauczycieli, którzy po ukończeniu seminarium nauczycielskiego pracowali w szkołach guberni radomskiej, nieco się zwiększyła. Jest to zaskakujące, w tym czasie bowiem nauczycieli kształciło tylko jedno seminarium. Ta korzystna zmiana wynikała przede wszystkim z polityki kadrowej, jaką prowadziły władze w Kielcach i Radomiu, dokładające starań, by zatrudniać tylko absolwentów seminarium nauczycielskiego. Również w latach czterdziestych - jak wynika z wielu aktów nominacyjnych - „Kurator obsadzał wakujące posady absolwentami seminarium nauczycielskiego. Od 1851 r. posady nauczycielskie obejmowali tylko - zgodnie z zarządzeniem kuratora - absolwenci seminarium radzymińskiego" 25 . Dodać tu należy, że najliczniejsza grupa takich nauczycieli pracowała wtedy w powiatach sandomierskim i opatowskim.

Najogólniej można powiedzieć, że poziom przygotowania zawodowego nauczycieli był bardzo różny. Przyznać trzeba, że pełne przygotowanie do zawodu mieli absolwenci seminariów nauczycielskich, szkół wojewódzkich i gimnazjów. Jednakże należy pamiętać, że absolwenci instytutów nauczycielskich posiadali mniejszy zasób wiedzy ogólnej od wychowanków szkół wojewódzkich i gimnazjów. Przybywali oni do seminarium najczęściej po ukończeniu szkoły elementarnej, bądź 2-3 klas szkoły średniej. Dlatego w czasie pobytu w seminarium nie mogli otrzymać wykształcenia z zakresu programu nauczania w szkole wojewódzkiej lub gimnazjum. Mieli oni jedynie lepsze przygotowa-

\footnotetext{
${ }^{24}$ R. Wroczyński, Dzieje Oświaty Polskiej do roku 1795, Warszawa 1980, s. 116.

25 W. Caban, op.cit., s. 102.
} 
nie pod względem pedagogicznym ${ }^{26}$. Natomiast nauczyciele, którzy ukończyli szkoły wydziałowe (powiatowe) czy tylko elementarne, takiego przygotowania nie posiadali.

Ważnym wydarzeniem dla oświaty Królestwa stał się moment, kiedy to po śmierci Mikołaja I nastąpiło zelżenie ucisku narodowego. Wyrażało się ono odwołaniem w marcu 1861 r. kuratora warszawskiego Pawła Muchanowa i przywróceniem w miejsce Warszawskiego Okręgu Naukowego - Komisji Wyznań Religijnych i Oświecenia Publicznego oraz powołaniem na jej stanowisko dyrektora, margrabiego Aleksandra Wielopolskiego. Wtedy postanowiono przeprowadzić reformę szkolnictwa elementarnego i średniego oraz reaktywować zlikwidowane w czasie represji popowstaniowych szkoły wyższe. Zapowiedziano też powołanie Rady Stanu oraz rad miejskich, powiatowych i gubernialnych jako organów samorządu Królestwa ${ }^{27}$.

Kielce, które w 1809 r. włączono do Księstwa Warszawskiego, wcześniej - bo od 1795 do 1809 r. - pozostawały w zaborze austriackim, od 1816 r. stały się integralną częścią Królestwa Polskiego i administracyjnie podlegały zaborczym władzom rosyjskim.

Zamierzeniem niniejszego opracowania było odsłonięcie i ukazanie podstawowych decyzji, warunkujących rzeczywistość szkolnictwa w pierwszej połowie XIX w. Cechę podstawową tych decyzji stanowiły koncepcje kształcenia nauczycieli i usprawnianie oświaty na wszystkich jej poziomach, przynajmniej do powstania listopadowego.

W czasach Księstwa Warszawskiego (1807-1815) najważniejsze znaczenie miała odezwa „O urządzeniu szkół miejskich i wiejskich elementarnych” (1808), która równocześnie wprowadzała obowiązek szkolny. Ten doniosły fakt spowodował, że do $1812 \mathrm{r}$. powstało około 500 nowych szkół elementarnych. Równolegle z zakładaniem szkół początkowych dokonano gruntownej reformy seminariów nauczycielskich w Poznaniu i Łowiczu w oparciu o pedagogiczne koncepcje Jana I. Felbigera ${ }^{28}$, Augusta H. Niemeyera, autora znanej książki pt. Grundsätze der Erziehung und unterrichts ${ }^{29}$. Tę książkę S. Wołoszyn nazwał „sumą pedagogiki epoki, najbardziej pewną i najbardziej niezawodną, powszechnie zrozumiałą i powszechnie możliwą do zastosowania, najszerszą i najtrwalszą empiryczną postawą teorii wychowania"30.

Poza szkołami elementarnymi poszerzyła się również sieć szkół średnich, w których po raz pierwszy przeprowadzono egzaminy dojrzałości w $1814 \mathrm{r}$.

Dla całego szkolnictwa podstawowe $\mathrm{i}$ istotne znaczenie miało wznowienie działalności Towarzystwa do Ksiąg Elementarnych, któremu przewodniczył S.B. Linde. Do suk-

\footnotetext{
${ }^{26}$ J. Dutkiewicz, Historia Państwowego Seminarium Nauczycielskiego Męskiego im. Marszałka Józefa Pitsudskiego, Łowicz 1934, s. 32 - 35.

${ }^{27}$ R. Wroczyński, op.cit., 1980, s. 122. Także: K. Poznański, Oświata i szkolnictwo w Królestwie Polskim 1831-1869. Lata zmagań i nadziei, Warszawa 2001.

28 A.K. Wiedemann, Die pedagogische Bedeutung Abtes Ignatz v Felbiger. Ein Beitrag zur Geschichte der Pedagogik des XVIII Jahrhunderst, Plauen 1890. Także: H. Grünhagen, Schlesien unter Friedrich d. Grossen, t. 2, Breslau 1892 .

29 A.H. Niemeyer, Grundsätze der Erziehung und Unterrichts, Halle 1796.

${ }^{30}$ S. Wołoszyn, Rozprawa Edwarda Czarneckiego o nauczycielu, przedstawiona w 1808 r. Towarzystwu Warszawskiemu Przyjaciół Nauk, „Przegląd Historyczno-Oświatowy” 1976, nr 2, s. 232.
} 
cesów oświatowych Izby Edukacyjnej należy również zaliczyć otwarcie dwóch szkół wyższych w Warszawie: (Szkoła Prawa - 1808 i Szkoła Lekarska - 1809), będących zalążkiem Uniwersytetu Warszawskiego.

Były to więc wcale niemałe osiągnięcia, uzyskane w trudnych warunkach społeczno-ekonomicznych, kiedy skromny budżet Księstwa Warszawskiego obciążało utrzymanie armii napoleońskiej i kontrybucja płacona na rzecz Francji.

Przeobrażenie w 1812 r. Izby Edukacyjnej w Dyrekcję Edukacji Narodowej, którą kierował S. Kostka Potocki, nie przyniosło zmian na lepsze. Klęska Napoleona pod Moskwą i zajęcie Warszawy przez Rosję zahamowało wszelki rozwój oświaty w Królestwie Polskim (1815-1832). Sprawami oświaty zajmowała się Komisja Rządowa Wyznań Religijnych i Oświecenia (Publicznego). Jej ministrem do 1820 r. był S. Kostka Potocki. Kontynuowana przez niego polityka oświatowa z czasów Księstwa Warszawskiego okazała się najbardziej owocna w sferze szkolnictwa elementarnego. Chociaż pozytywne zmiany zaistniały również w szkolnictwie średnim, któremu wyznaczono bardziej utylitarne cele.

Pojawiające się wtedy szkoły rzemieślniczo-niedzielne oraz zawodowe przygotowywały młodzież do wykonywania określonej pracy. Na mapie edukacyjnej Księstwa pojawiły się szczególnie ważne instytucje: Szkoła Górnicza w Kielcach (1816), Szkoła Leśnictwa w Warszawie (1818), Instytut Agronomiczny w Marymoncie (1820), Szkoła Budownictwa i Miernictwa w Warszawie.

Najważniejszym jednak wydarzeniem stało się założenie Uniwersytetu Warszawskiego. Dekret wydany w 1816 r. przez cara Aleksandra I dał podstawę rozpoczęcia wykładów na tej uczelni w $1817 \mathrm{r}$.

Tę pomyślną tendencję zahamował Stanisław Grabski, od 1820 r. następca S. Kostki Potockiego. Już w 1821 r. zniósł on obowiązkowość składek szkolnych. Ten uległy Rosji polityk doprowadził do zamknięcia większości szkół wiejskich. Zauważmy, że w dziesięcioleciu 1820-1830 ich liczba spadła z 880 do 329. Zwiększyła się natomiast liczba szkół elementarnych w miastach - z 342 do 412.

Joachim Lelewel, minister Wyznań Religijnych i Oświecenia Publicznego w czasie powstania listopadowego, w odezwie wydanej do nauczycieli apelował o kontynuowanie zajęć szkolnych mimo trwającej wojny i w ogólnym zarysie informował o projektowanej reformie oświaty, przede wszystkim szkolnictwa elementarnego. Jej projekt ogłosił już Kajetan Garbiński, który zastąpił J. Lelewela na stanowisku ministra Wyznań Religijnych i Oświecenia Publicznego ${ }^{31}$. Ów projekt zapowiadał: „Oświata powinna być powszechna, podnosić świadomość narodową, doskonalić moralność społeczną, ugruntować poczucie sprawiedliwości i wolności, a jednocześnie służyć celom utylitarnym, rozwijać zdolności narodu, bez których nie można wywalczyć i utrzymać niepodległość narodu" 32 .

Niestety, upadek powstania przekreślił te uniwersalne zamierzenia oświatowe Rządu Tymczasowego. Popowstaniowe represje spowodowały nie tylko zamknięcie Uniwersy-

\footnotetext{
31 J. Draus, R. Terlecki, op.cit., s. 75-79.

32 Ibidem, s. 80.
} 
tetu Warszawskiego, Instytutu Agronomicznego w Marymoncie, ale też likwidację wielu placówek i instytucji oświatowych, w tym działającego od 1801 r. Towarzystwa Przyjaciół Nauk ${ }^{33}$.

Na podstawie ustawy szkolnej z 1833 r. dokonano podziału szkolnictwa na szkoły elementarne, obwodowe, a po wprowadzeniu w 1837 r. powiatów - szkoły powiatowe i gimnazja oraz szkoły guberniane, po zmianie województw na gubernie. Znacznemu okrojeniu uległy programy nauczania w szkołach elementarnych. A dokonana weryfikacja nauczycieli zmierzała do pozbawienia pracy pedagogów niepewnych politycznie. Cały system szkolny poddano surowemu nadzorowi policyjnemu.

Najbardziej niebezpieczny cios zadała szkolnictwu elementarnemu ustawa szkolna z 1851 r. znosząca obowiązek szkolny. Ta niekorzystna sytuacja uległa poprawie dopiero w 1861 r. Reaktywowana wtedy Komisja Wyznań i Oświecenia Publicznego, kierowana przez margrabiego Aleksandra Wielkopolskiego, podjęła dzieło repolonizacji oświaty oraz przygotowała reformę szkolnictwa. „Ustawa o wychowaniu publicznym w Królestwie Polskim", zatwierdzona przez cara 20 maja 1862 r., poprawiła kondycję materialną i przyniosła poszerzenie sieci szkolnictwa elementarnego zarówno miejskiego, jak i wiejskiego, pozostającego na utrzymaniu gminy i dworu. I chociaż ustawa nie wprowadzała obowiązku szkolnego, to jednak zachowanie bezpłatności nauczania przyciągnęło dzieci do szkoły i przyczyniło się do upowszechnienia oświaty elementarnej. W końcu umożliwienie zakładania prywatnych szkół początkowych, stało się ważnym wydarzeniem w kształceniu początkowym dzieci ${ }^{34}$.

Ale na tym nie kończyły się poczynania A. Wielopolskiego w sferze reformy szkolnictwa. Zgodnie z duchem ustawy zreformowaniu zostało poddane także szkolnictwo średnie. I co ważne, szkoły średnie uległy podziałowi na pięcioletnie szkoły powiatowe, w których ostatnie klasy miały charakter sprofilowany: ogólny, techniczny i pedagogiczny oraz siedmioletnie gimnazja programowo ukierunkowane filologicznie, nie zaś, jak wcześniej było, realnie.

Akcentując dalej wartość reformy, nie wolno pominąć sprawy zasadniczej. Chodzi mianowicie o duże uczelnie wyższe: pierwszą była Szkoła Główna (uniwersytet) w Warszawie, drugą natomiast Instytut Politechniczny i Rolniczo-Leśny w Puławach. Nie możemy też zapominać, że od 1857 r. działała w Warszawie Akademia Medyko-Chirurgiczna $^{35}$.

Opisane przemiany w oświacie wynikające z podejmowanych reform uznać należy za właściwie ukierunkowane. Prawdziwym łącznikiem, charakteryzującym dokonywane przemiany, była idea upowszechnienia oświaty na poziomie elementarnym. Owo pragnienie dowartościowania szkolnictwa początkowego stanowiło kontynuację przewodniej myśli Komisji Edukacji Narodowej. I można powiedzieć, że w tej właśnie myśli

\footnotetext{
${ }^{33}$ Ibidem, s. 83. Także: ... z Niego my wszyscy, 200 lat Towarzystwa Królewskiego Warszawskiego Przyjaciół Nauk, Ciechanów 2001 (praca zbiorowa, brak redaktora).

34 J. Draus, R. Terlecki, op.cit., s. 85-86.

35 Ibidem, s. 85-86.
} 
ujmowany jest wymóg traktowania oświaty elementarnej jako imperatywu ideowego postępu kulturalnego i cywilizacyjnego społeczeństwa polskiego, w szerszym horyzoncie czasowym.

\title{
School reforms in the first half of the nineteenth century
}

\begin{abstract}
Summary
The present text outlines the school reforms carried out in the first half of the nineteenth century. As the timeframe suggests, these reforms were launched and implemented by the then authorities of the Duchy of Warsaw and the Russian authorities administering the Russian part of partitioned Poland. The author attempts to indicate the most important goals and assumptions of the reforms as well as their immediate educational and social consequences. The text is far from being a comprehensive description of the problem but rather serves as an introduction to the substance of the issue under investigation and its political and economic conditioning.
\end{abstract}

